\title{
逆向マスキング・パラダイム下の体性感覚反応時間に及ぼす 無自覚的知覚の影響
}

\author{
高井晋次1),3） 今中国泰1）北 一 郎1） 森 周 司2) \\ The effect of perception without awareness on somatosensory \\ reaction time using a backward masking paradigm
}

Shinji Takai ${ }^{1,3}$, Kuniyasu Imanaka ${ }^{1}$, Ichiro Kita ${ }^{1}$ and Shuji Mori ${ }^{2}$

\begin{abstract}
This study examined the effect of perception without awareness on somatosensory simple reaction time using a backward masking paradigm in nine subjects ranging in age from 21 to 38 years. In the backward masking paradigm, two types of electrical stimuli differing in intensity (one type ranging from 1.2 to 1.5 times the sensory threshold of each subject, and the other ranging from 4 to 5 times the threshold) were successively delivered with a 40-ms interstimulus interval to the subjects' right median nerve at the wrist through disk electrodes. There were three stimulation conditions: weak stimulus alone, strong stimulus alone, and double stimulation (which was the backward-masking condition, with a weak stimulus always preceding a strong one). The subjects were asked to respond to either the weak or the strong stimulus as quickly as possible by clicking on the computer mouse button, without any knowledge that the double stimulation would be included in the experimental trials. The results showed that the mean reaction time for double stimulation was significantly shorter than that for the strong stimulus condition, and that the reaction time for the weak stimulus was the longest among the three conditions. The latter result indicated that the weak stimulus could not be perceived quickly. All subjects reported that they did not perceive the weak, preceding stimulus used for double stimulation-suggesting that the weak stimulus was masked by the following strong stimulus. Therefore, the weak stimulus, without the subject being aware of it, may have facilitated the preparatory processes for performing response actions, resulting in the shorter reaction times observed with double stimulation. These findings are discussed in terms of several conceptual and empirical models of information processing for sensation, perception, and preparation of motor responses in simple reaction time under backward masking.
\end{abstract}

Key words: somatosensory, simple reaction time, backward masking, parallel information-processing

(Japan J. Phys. Educ. 45: 333-346, May, 2000)

1) 東京都立大学理学研究科身体運動科学専攻 厂192-0397 東京都八王子市南大沢 1-1

2）富山県立大学工学部一般教育等(知覚心理学) 于939-0398 富山県射水郡小杉町黒河5180

3）現所属 : ニューラル有限会社 (開発部) ₹190-0022 東京都立川市錦町 3-1-2
1. Tokyo Metropolitan University, Faculty of Science, Department of Kinesiology, 1-1 Minami-Ohsawa, Hachioji, Tokyo 192-0397

2. Toyama Prefectural University, Faculty of Engineering, 5180 Imizu-gun, Kosugi-machi, Toyama 939-0398

3. Current address: Neural Ltd. Co., 3-1-2 Nishiki-cho, Tachikawa, Tokyo 190-0022 
キーワード：体性感觉、単純反応時間, 逆向マスキン グ，並列情報処理

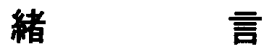

われわれの日常的な運動行動の多くは，外界か らのさむざをな刺激に対する知覚体験を伴いなが ら遂行される。しかし，環境刺激や自己の動作の すべてに意識あるいは注意を向けるわけではな く，むしろ特定の刺激や意図的な手足の動き以外 にはほとんど注意が向けられることはない，特に スポーツ動作では，刺激認知や状況判断が意識に 上る前に自然に体が動いてしまう，ということも しばしば経験することである。こういった経験的 な事実からも，われわれの運動行動では意識に上 らないさまざまな刺激・情報が合目的的に適切に 処理され，スムーズな運動・動作の遂行を可能に していると考えられる.

知覚体験を伴わない刺激の入力（無自覚的な知 覚）が運動行動に少なからず影響を及ぼすことに ついては, 近年, 神経心理学や行動科学領域にお ける症例や実験的事実として報告されるようにな ってきた。たとえば，脳損傷による半側感覚麻痺 患者を調べた Rossetti et al. (1995) の研究では, 目隠しをした被験者の麻疩側に触覚刺激を与える と, 被験者は半側感覚麻瘒であるが故にその刺激 点の場所がどこであるかを答えることはできない が，反対側の手で反応させるとほぼ正しい位置を 指し示す，ということが報告されている．また視 覚に関しても，右側一次視覚野に脳損傷を負った 患者の左視野（視覚を失った半側視野）に刺激を 呈示するとき，その刺激がまったく見えないはず であるにもかかわらずその刺激位置へのリーチン グ動作はかなり正確に行われる，という盲目視 （blindsight）の例が報告されている(Weiskrantz, 1980; Weiskrantz et al., 1974).これらは，知覚 体験を伴わない刺激がその刺激に対する運動反応 に関わっていることを示す典型的な症例といえ る.

健常被験者における無自覚的知覚と運動反応に 関しては，逆向マスキング・パラダイム下の反応 課題を用いた研究（Fehrer \& Biederman, 1962;
Fehrer \& Raab, 1962; MacIntyre \& McComas, 1996; Taylor \& McCloskey, 1990, 1996） が報告 されている、それらの研究では，刺激強度の異な る強弱 2つの刺激を弱一強の順で 0-81 $\mathrm{msec} の$ 間隔をおいて呈示し，それらの刺激に対してでき るだけすばやく反応させるという反応課題が用い られている．この実験パラダイムでは，刺激強度 差をある程度以上に設定すると，先行する弱い刺 激の感覚が後続刺激によってマスクされるという 逆向マスキング効果が生じ, 被験者は後続刺激に 対してのみ知覚を体験することになる．しかし， そのときの反応時間は, 知覚体験を伴わない先行 刺激に対する反応とみなせる結果が示されてい る.この逆向マスキング一反応時間の現象も，脳 損傷患者の症例報告と同様, 知覚体験を伴わない 刺激が何らかのかたちで運動反応に大きく関与し ていることを示す知見といえる.

逆向マスキング・パラダイムを用いた研究は, 知覚心理学領域では比較的古くから頻繁に行われ てきているが，そのほとんどは視知覚に関するも のである (Eriksen \& Collins, 1965; Fehrer \& Biederman, 1962; Fehrer \& Raab, 1962; Harrison \& Fox, 1966; Neumann \& Klotz, 1994; Schiller \& Smith, 1966; Taylor \& McCloskey, 1990, 1996; Thompson, 1966; White, 1976)。体性感覚や皮膚 感覚に関する逆向マスキング一反応時間研究につ いては，それらが運動と深い関わりを持っている にもかかわらず，これまでほとんど報告されてい ない，もちろん，体性感覚や皮膚感覚そのものに 関しては, 神経生理学を中心に古くから研究対象 とされてきており, 知覚体験に直接・間接的に関 連する研究も多数報告されている，たとえば，感 覚閾值 (e.g., Johansson \& Vallbo, 1979), 感覚 閾値と誘発電位·事象関連電位（e.g., Gomes, 1998; Libet et al., 1967, 1992)，順向・逆向マス キング (Abramsky et al., 1971; Craig \& Evans, 1995; Kirman, 1984; Laskin \& Spencer, 1979; Schmid，1961）などを取り扱った研究が多数み られる. しかし, 体性感覚あるいは皮庙感覚の逆 向マスキングと運動反応の関係を直接検討した研 究は, MEDLINE および Psychological Abstract 
を調べた限りでは，MacIntyre and McComas (1996) の研究があるのみである.

MacIntyre and McComas (1996) は,リーチン グ動作による選択反応課題を逆向マスキング・パ ラダイム下で実施している. 彼らの用いた逆向マ スキング・パラダイムでは, 先行刺激として感覚 閵值付近の弱い電気刺激を，また後続刺激にはそ の約 3 倍の強度の刺激を用い，それらを刺激呈 示間隔81 msec で呈示した. 彼らは，この先行一 後続刺激条件（Both 条件）のほかに，先行刺激 のみ，後続刺激のみをそれぞれ単独呈示する条件 も加え，それぞれの反応時間を比較した．被験者 への教示は, 弱い刺激が呈示されたら身体正面左 前方のターゲットへ，また強い刺激に対しては右 前方ターゲットへのリーチング動作をできるだ すばやく行うようにというものであり, Both 条 件の刺激呈示の存在については何む教示しなかっ た。したがって，Both 条件下で，むし被験者の リーチングが左のターゲットに対して行われると すれば，被験者は弱い刺激すなわち先行刺激を知 覚したことになり，右へのリーチングであれば強 い刺激である後続刺激を知覚したことになる。実 験の結果, Both 条件下では, 被験者のリーチン グ動作のほとんどは右のターゲットに対して行わ れていたことから，先行刺激が知覚されていなか ったものと推察された。他方, 反応時間について みると, Both 条件下の反応時間は，先行刺激あ るいは後続刺激のみを単独で呈示したときの反応 時間よりも有意に短いものであった。これらの結 果にもとついて, MacIntyre and McComasは, 先行刺激に対しては知覚体験が生じていなかった にもかかわらず，その先行刺激がトリガーとなっ て刺激の同定・弁別および反応選択過程が無自覚 下で活性化・促進され，その結果 Both 条件下の 反応時間が短くなったと推察した.

MacIntyre and McComas (1996) の報告は, 逆 向マスキング現象が視覚たけではなく体性感覚に もみられるより一般的な現象であることを示した 重要な研究といえるが, 実験方法上に以下に示す 若干の問題があった. 彼らは, 反応時間測定とし てリーチング動作開始時点の筋電図（三角筋）反
応時間を用い, 知覚体験に関しては, リーチング 動作が左右どちらのターゲットに対して行われた のかによって, 被験者の知覚した刺激が先行刺激 あるいは後続刺激のどちらだったのかを同定して いる.このように, 選択反応の結果によって知覚 体験を同定しようとする方法は, 多くの研究者 (Neumann \& Klotz, 1994; Taylor \& McCloskey, 1990，1996）によって採用されてきていることか ら，一般的には有効な方法といえるのかもしれな い.しかし MacIntyre and McComasの方法で は，測定された反応時間よりも後の時点，つまり 動作が開始された後, リーチング動作を実行して いる間に刺激弁別とターゲット選択が行われてい たという可能性が考えられる.さらに，選択反応 課題においては, 刺激の検出・同定・弁別を含む 知覚過程, および反応選択・ 反応プログラミング からなる運動準備過程, さらには運動命令の出力 過程など一連の情報処理過程すべてが含まれてお り, 得られた反応時間を特定の情報処理段階の遅 延・短縮として解釈するのはきわめて困難であ る. 事実, 彼らが論文中で展開した知覚一反応情 報処理に関する考察は数多くの前提条件に基づい たものとなっており，知覚体験の有無と反応時間 の関連を明快に論議することに必ずしも成功して いるとはいえない.

本研究では, MacIntyre and McComas (1996) のいくつかの問題点を考虑するために, 選択反応 ではなく単純反応課題を採用し, 逆向マスキング ・パラダイムによる無自覚的知覚の体性感覚反応 時間に及ぼす影響を検討した。問題点の一つであ った知覚体験の同定に関しては，選択反応の結果 からの事後的な（post-hoc）同定ではなく, あら かじめ逆向マスキングが確実に生じるような刺激 強度を設定することにより，マスキング効果の生 起を保証した．また選択反応課題で考虑すべき刺 激の同定 - 弁別や反応選択などの情報処理過程に 関しては，単純反応課題を採用することにより議 論の対象から除いた。一般に，単純反応時間は刺 激検出までに要する時間, および運動準備過程と その出力に要する時間から構成されると考えられ ている (Luce, 1986). したがって, 強弱 2つの 
刺激を用いる逆向マスキング・パラダイム下の単 純反応課題においても，知覚過程に関しては，刺 激検出およびその知覚体験の有無，あるいはそれ らが生じるまでの時間が反応時間に直接影響する こととなる．運動準備過程については，単純反応 課題では反応動作があらかじめ定められているた め反応選択過程は含まれず，また反応動作に伴う 筋活動も基本的には同じであることから反応プロ グラミング過程もほほ一定であると仮定できる.

したがって, 本研究の単純反応課題では, 反応選 択抢よび反応ブログラミングの情報処理過程を反 応時間の影響因子として考慮する必要はないもの と思われる.

以上のように, 本研究では, 逆向マスキング . パラダイム下の単純反応課題を採用することによ り，刺激の同定 ·并別および反応選択 · 反応プロ グラミング過程を論議の対象からはずし，刺激の 検出に関する知覚体験の有無と反応時間の関連性 を検討することを試みた。

\section{方法}

\section{1. 被験者}

被験者は, 健康な成人男子 9 名（年龄21-38才） で，実験内容を説明し同意を得た上で実験を実施 した.

\section{2. 実験課題}

本研究で用いた単純反応課題では，まず予告刺 激（音刺激）を呈示し，ランダムに設定した 2$3 \sec$ の先行時間（foreperiod）の後, 電気刺激 を呈示し，それに対してできるたけすばやく右手 第 2 指によるコンピュータ・マウスのクリック 動作を行わせるというものであった. 電気刺激呈 示には, 電気刺激装置（日本光電, SEN-3301) およびアイソレータ（日本光電, SS-201J）を用 い, 持続時間 $0.2 \mathrm{msec}$ の定電圧単発矩形波を， 銀一塩化銀血電極（直径 $12 \mathrm{~mm}$ ) を介して被験 者の右手手根部正中神経に経皮的に与えた. 被験 者が電気刺激を知覚した部位は, 内省報告より手 掌部と第 $1,2,3$ 指付近であることが確認された。 反応時間測定にはグラフィカル・プログラミング
言語 LabView（National Instruments）によるソ フトウエアを用い, 刺激呈示からマウスのクリッ クをでの時間を反応時間とした。なおこのクリ ック動作による反応時間は, 筋電図反応時間より 約 $100 \mathrm{msec}$ 長いことが予備実験によって明らか となった，本研究では，反応時間を逆向マスキン グ・パラダイム条件と他の刺激呈示条件間で相対 的に比較したため，必ずしも筋電図反応時間を使 う必要がなかったこと，および電極添付などによ る被験者の心理的負担をできるだけ軽減するため に，マウスのクリック動作による反応時間の方を 採用した。

\section{3. 刺激呈示条件}

刺激呈示条件は，(1)逆向マスキング・パラダイ ムにもとづき，先行刺激 (弱刺激) の呈示後40 $\mathrm{msec}$ の時点で後続刺激（強刺激）を呈示する条 件（Double条件，これは MacIntyre \& $\mathrm{McCo}$ mas, 1996, の Both 条件に相当)，(2)先行刺激を 単独で呈示する条件 (Weak 条件)，および(3)後 続刺激を単独で呈示する条件 (Strong 条件)，の 3 条件とした.これら 3 条件の反応時間を比較す ることにより, Double 条件の反応時間が先行刺 激あるいは後続刺激のどちらに反応したものであ るかを検討した。 なお，被験者には強弱いずれの 刺激にもできるだけすばやく反応するようにとの み教示し, Double 条件による刺激呈示について は何も知らせなかった.

先行刺激および後続刺激それぞれの刺激強度 は，先行刺激が後続刺激によって確実にマスクさ れる（先行刺激を被験者に知覚させない）強度を あらかじめ調べた上で被験者ごとに設定した。す なわち, 各被験者の感覚闘値を極限法により測定 し，それを目安として，先行刺激については単独 呈示でからうじて知覚可能な強度とし, 後続刺激 は，十分なマスキング効果を生じさせるために先 行刺激との強度差をできるだけ大くし，かつ痛 みを伴わず筋収縮もほとんど誘発されない強度と した. その結果, 先行刺激は感覚閾値の1.2-1.5 倍, 後続刺激は感覚閾值の 4-5 倍の刺激強度と なった。 


\section{4. 分析方法}

刺激呈示条件（Weak, Double, Strong）間す べての組み合わせに対し，対応のある $t$-検定に よって平均反応時間の差の検定を行った. なお， 同一データセットに対して $t$-検定を 3 回繰り返 すこととなったため, Bonferroni の方法に従い, 有意水準を $5 \%$ からその $1 / 3,1.67 \%$ に引下げ た. Double 条件下の反応時間については, 先行 刺激および後続刺激の両者から測定し, Weak 条 件あるいは Strong 条件下の反応時間とそれぞれ 比較した.

\section{5. 手順}

実験は, 以下の手順により, 感覚閾値測定, 単 純反応課題, 内省報告聴取抢よび感覚閾值再測定 を実施した。

1）感覚閾値測定

はじめに，極限法（上昇，下降系列刺激）に上 る感覚間值を測定した。 上昇系列の刺激呈示で は, 感覚閾値以下の微弱な刺激強度から段階的に 強度を増していき, 被験者が刺激を自覚的に知覚 できた時点の強度を記録した。また下降系列で は, 自覚的知覚が容易である強度から段階的に弱 くしていき，知覚できなくなった強度を記録し た。それぞれ 3 試行, 計 6 試行をランダムな順 序で実施し，それらの平均値を各被験者の感覚闘 值とした。既に述べたように，Weak 刺激および Strong 刺激はこの感覚闘値を目安に設定したも のである.

\section{2) 単純反応課題}

実験試行前に被験者に課題を説明し，その後， 各刺激呈示条件下（Weak, Double, Strong）で 数試行ずつランダムに練習を行わせた. 本試行は 条件ごとに10試行, 計30試行を 6-8 sec の試行間 隔でランダムに行わせ，休嚊をはさんでこれを 2 セット, 計 60 試行を実施した. 実験終了後, 得 られた反応時間データのうち，200-700 $\mathrm{msec}$ (EMG 反応時間ではおよそ100-600 msecに相 当）の範囲外のデータを尚早・遅延反応とみな し，分析の対象からはずした。なお，それらを補 足するための追加試行は行わなかった．また，キ
ヤッチ試行については, 先行時間 (foreperiod) をランダムに設定したことおよび3つの刺激呈 示条件をランダムに呈示したことから，特に挿入 しなかった。

3）内省報告の聴取および感覚間値再測定 単純反応課題終了後, 内省報告を聴取し, 課題 中に Double 条件による刺激呈示に気づいたかど うかを調べた。 また, 実験中の自覚的な知覚感度 の変化については, 課題終了後, 感覚閾値の測定 を再度実施し, 課題前後の感覚閥值の差を対応の ある $t$-検定により比較した。 その結果, 有意差 は認められなかった $(p>.05)$.

\section{結果}

全被験者の刺激呈示条件別の反応時間を Fig. 1 に示した. Double 条件の反応時間は後続刺激 からの反応時間のみを示した，反応時間の条件間 パターンはすべての被験者に共通しており， Weak 条件の反応時間が最も長く, ついで

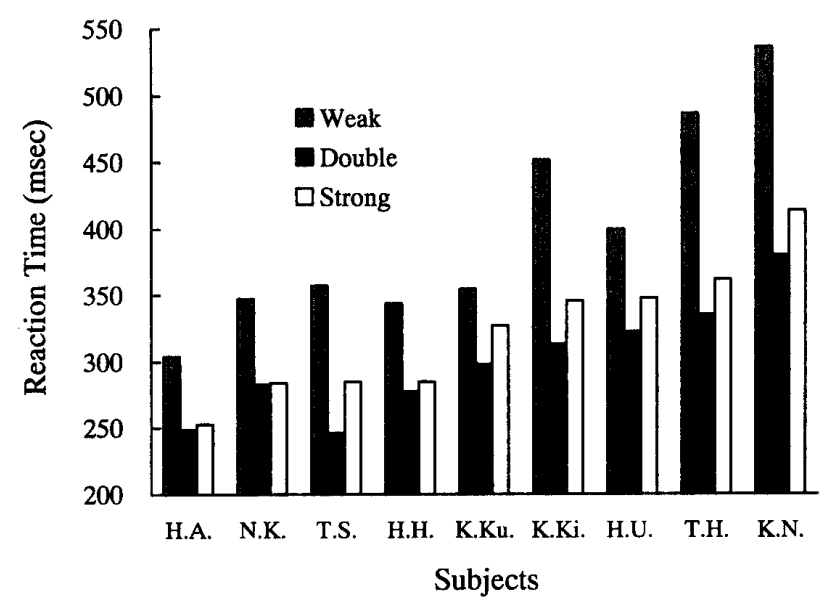

Fig. 1 Mean reaction times in msec for the Weak, Double, and Strong stimulation conditions for each subject. The reaction times for the Double condition were measured as the duration from the onset of the second stimulus. All subjects showed similar patterns of reaction times for the three conditions. The reaction times for the Weak condition were the longest among the three stimulation conditions, while the reaction times for the Double condition were the shortest. 
Strong, Double の順で反応時間が短くなった. 各被験者の反応時間は, 尚早・遅延反応の試行を 除いた平均値である。これらの被験者のうち，尚 早反応が生じた被験者は H.A. と N.K.の 2 名で, 被験者 H.A. には，各条件 20 試行中，Double 条 件で 1 試行, Strong 条件で 3 試行の尚早反応が みられ，被験者 N.K.には，Weak, Double, Strongの各条件それぞれに $3,4,4$ 試行の尚早反 応が認められた。この 2 名には遅延反応はまっ たくみられなかった。これらの結果から，被験者 H.A. と N.K. はいずれも試行全般に尚早反応傾 向が反映されていた可能性が考えられ, 以後の統 計分析の対象から除外した．他の被験者について は，遅延反応が K.Ki.に 2 試行，T.H.に 1 試 行，K.N.に 4 試行認められたが，これらはいず れもWeak 条件下で生じており，Weak 条件下 の刺激がきわめて弱かったことがその原因と考え られた。したがって，これら 3 名の遅延反応は 全般的な反応傾向を反映しているとは考えられ ず，そのまま分析対象として採用した。

被験者 H.A. と N.K. を除く 7 名について，尚 早・遅延反応を除外したうえで各刺激呈示条件に おける平均反応時間を求めた（Fig. 2). Weak および Strong 条件下の平均反応時間は，それぞ れ418 $\mathrm{msec}(\mathrm{SD}=69.0), 338 \mathrm{msec}(\mathrm{SD}=41.9)$ であった. Double 条件下の平均反応時間につい ては，先行刺激から測った反応時間が $350 \mathrm{msec}$ $(\mathrm{SD}=39.6)$ ，後続刺激からの反応時間は 310 $\mathrm{msec}(\mathrm{SD}=39.6)$ であった。これら反応時間の 有意差検定を対応のある $t$-検定により行ったと ころ，先行刺激からの反応時間の比較として Double とWeak 間 $(t=4.310, p<.005)$ ，後続刺 激加らの反応時間の比較としてDouble と

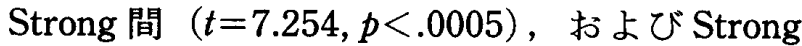
とWeak 間（ $t=5.661, p<.002)$ のそれぞれに有 意差が認められた。

実験終了後に実施した内省報告聴取では，被験 者全員が，弱刺激あるいは強刺激のどちらかの刺 激しか感じなかったと報告した。つまり，Double 条件下においては後続刺激のみが呈示された と感じており，先行刺激の存在には気づいていな

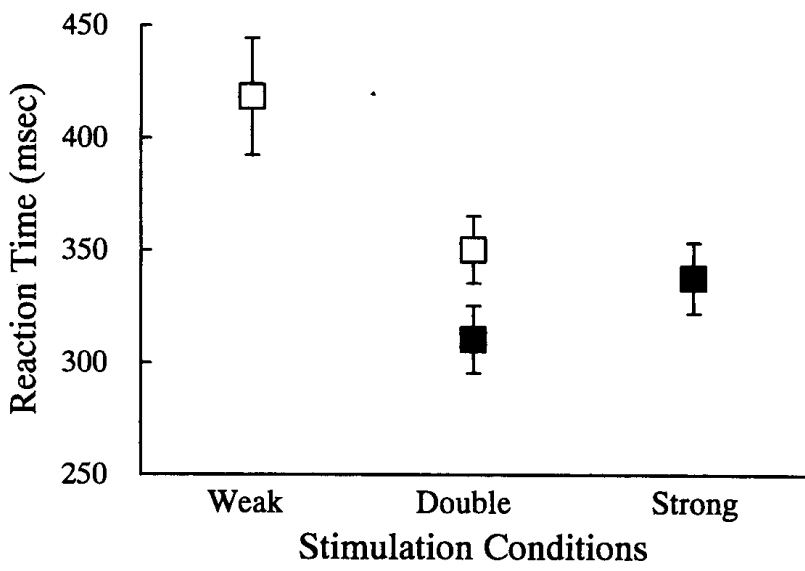

Fig. 2 Mean reaction times in msec for the Weak, Double, and Strong stimulation conditions. Open squares $(\square)$ indicate the reaction times measured from the onset of the weak stimulus (the first stimulus for the Double condition) and filled squares ( $\boldsymbol{\omega}$ ) indicate the reaction times from the onset of the strong stimulus (the second stimulus for the Double condition). Vertical bars attached to each square symbol indicate standard errors of mean.

かったことが確認された.

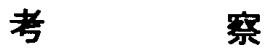

先行刺激から測定した Double 条件の反応時間 $(350 \mathrm{msec})$ は, 先行刺激を単独で呈示した Weak 条件の反応時間 $(418 \mathrm{msec})$ よりも有意に短く, また後続刺激から測定した Double 条件の反応時 間 $(310 \mathrm{msec})$ は，後続刺激単独呈示である Strong 条件 $(338 \mathrm{msec})$ よりも有意に短いこと が明らかとなった．したがって，Double 条件下 の反応時間は，単に先行刺激あるいは後続刺激の ぞちらか一方に反応した結果生じたものではな く, 先行一後続刺激の相乗効果として生じたもの といえる。他方，Double 条件下の知覚体験につ いては，知覚体験を生じさせないような刺激強度 をあらかじめ設定しており，内省報告でも Double 条件と Strong 条件の判別ができなかったこ とが確認されたことから，知覚体験は生じていな かったものと考えられる. したがって，現象的に みれば，知覚体験が生じなかった先行刺激が後続 
刺激の知覚過程あるいは運動準備過程に影響を及 ほし，その結果，Double 条件下の反応時間が短 縮したものと推察される.

これらの結果は, 視覚 (Fehrer \& Biederman, 1962; Fehrer \& Raab, 1962; Neumann \& Klotz, 1994; Taylor \& McCloskey, 1990, 1996) および 体性感覚 (MacIntyre \& McComas, 1996) に関 する先行研究の知見と基本的には一致しており， 少なくとも視覚と体性感覚に共通する現象である と考えられる.ささらに, 先行研究 (MacIntyre \& McComas, 1996; Neumann \& Klotz, 1994; Taylor \& McCloskey, 1990, 1996) の多くで選択反応課 題が用いられていたが，この現象が選択反応課題 にしか含まれない刺激弁別や反応選択の情報処理 過程に依拠するものではなく，それらを含まない 単純反応課題でも生起することが示唆された。

以下の考察では, 本実験結果が示した一見逆説 的な現象，すなわち，知覚体験を伴わなかった先 行刺激が後続刺激の知覚過程あるいは運動準備過 程に影響を及ほすという現象について，初めに先 行刺激の検出と知覚体験を論じ, 次いで, 先行刺 激による知覚過程の促進および運動準備過程への 影響にそれぞれ言及する，最後に，この現象に関 わる情報処理様式を並列ないしはカスケード処理 の観点から考察する.

\section{1. 先行刺激の検出と知営体験}

先行刺激そのものの検出に関しては，先行刺激 を単独で呈示した Weak 条件の反応が Strong 条 件に比べて $80 \mathrm{msec}$ 遅かったことからみて，その 刺激検出は相対的に困難たったものと思われる. 一般に，単純反応時間は，刺激強度が高くなると そのべき乗に比例して短くなるというべき法則 (power law/Pieron law, Luce, 1986, 参照) に従 うとされている．このべき法則は, 視覚, 聴覚, 皮膚感覚いずれの感覚様相においても成り立つこ とが毫付けられている（Raab et al., 1961; Ulrich et al., 1998). 例えば, Burbeck ら (Burbeck \& Luce, 1982; Burbeck, 1985）の聴覚刺激を用いた 研究では, 闘值付近の弱い刺強度に対して平均 500-1000 msec にも及ぶ遅い単純反応時間が報
告されている．これらの知見を考慮すると，本研 究のWeak 条件下の平均反応時間が $418 \mathrm{msec}$ と，単純反応時間としてかなり遅かったのは，刺 激強度が感覚閾値のわずか1.2-1.5倍と弱かった ため，その検出あるいは知覚体験に至るまでにあ る程度長い時間を要したからであると解釈でき る.

このように，先行刺激はそれ自体，比較的知覚 が困難だったものと考えられるが，その先行刺激 が強刺激の前に呈示された Double 条件下では知 覚体験がほとんど生じていなかったと推察され た、しかし，知覚体験が生じなかったことは，必 ずしもその刺激が検出されていなかったことを意 味するものではない，例えば，Cheesman and Merikle（1986）は，ストループ効果を利用した プライミング研究の中で, 刺激内容が主観的には 判断できない場合でも，強制選択法により強制的 に判断結果を答えさせると，その正答率が90\% にも及ぶ場合があることを報告している。また， Libet et al. (1967) は，体性感覚誘発電位（SEP） を用いた感覚闇值に関する研究で, 知覚体験をま ったく伴わない感覚闘值以下の刺激でも，その入 力信号が大脳皮質に到達することを示している.

彼らは，感覚闌值の60-85\%という知覚できない 弱刺激を単一呈示し，そのときの脳波を500回加 算して SEP をもとめ，その SEP に約 $25 \mathrm{msec} の$ 潜時をむつ電位成分がわずかに生じていることを みいたした。この短潜時 SEP 成分は，感覚閾値 の 2 倍という明確な知覚体験を伴う刺激に顕著 にみられた皮質到達電位に相当していることか ら，弱刺激がたとえ知覚体験を伴わないとして も，その感覚入力は確加に大脳皮質に到達してい ると推察された。 さらに, Libet et al. (1967) は, 感覚閾值の60-75\%の弱刺激は単一呈示の場合に はをったく知覚できないものの，20-60 Hzで短 時間連続呈示すると知覚できるようになることを 報告し, 約 $25 \mathrm{msec}$ の潜時をもつ SEP 成分がサ ブリミナルな知覚に関与していると結論つけてい る.これらの知見は，知覚体験を伴わない刺激で む脳の活動を賦活し, 無自覚的に検出され得るこ とを示唆するむのといえよう. 
Double 条件下において先行刺激に対する知覚 体験が生じなかったのは，おそらく，刺激が検出 された後, 知覚体験が生じる前に後続刺激が呈示 され，それによって知覚体験の処理が中断してし まったためと考えられる. 知覚心理学において は，一般に，閾值付近の刺激の弁別や知覚体験は 検出過程の後の情報処理段階で生じると考えられ ている（例えば, Ejima \& Ohtani, 1989)。また 神経生理学的な立場からは, 刺激呈示による感覚 入力から知覚体験が意識に上るをでにはある程度 の時間がかかることが示唆されている. Libet et al.（1992）は，皮盧および皮質体性感覚野への刺 激を組み合わせた知覚実験から，感覚閾値付近の 皮庯刺激に対して知覚体験が生じるまでには最長 で500 msec 程度の時間がかかると主張しており， Gomes（1998）は少なくとも230 msecの時間が かかると推察している.

本研究では, Double 条件下における先行刺激 の検出と知覚体験の関係を詳細に論議することは 困難と思われるが，感覚入力信号が中枢に達する までの時間が比較的短い（約 $25 \mathrm{msec}$, Libet et al., 1967）ことを考虑すると，先行刺激の感覚入 力は中枢に到達し感覚信号として検出されていた むのと考えられる。亦た，刺激の入力から知覚体 験に至るまでには相対的に長い時間がかかる（約 $230 \mathrm{msec}$, Gomes, 1998）ことを考えると, Double 条件下では先行一後続刺激の呈示間隔が40 msecであったことから，先行刺激の知覚体験処 理が完了する前に後続刺激が呈示された可能性が きわめて高い．これらを仮定すれば，先行刺激の 知覚過程が後続刺激によって中断されたために知 覚体験が生じなかった，と解釈することが可能で あろう。

\section{2. 先行刺激による知覚過程の促進}

本実験では，Double条件下の反応時間が Strong 条件の反応時間よりも有意に短かったと いう結果が示された。抏そらく，先行刺激が知覚 体験を生じないままに後続刺激の知覚過程を促進 させたものと考えられるが，その促進効果につい ては, 少なくとも, 知覚の 2 過程説, 感覚入力
の時間加重, 直接プライミング，の 3 点に言及 することが可能と思われる。

単純反応課題における感覚・知覚情報処理が特 性の異なる 2 つ過程からなるという 2 過程説 は, 多くの研究者 (Breitmeyer \& Ganz, 1976; Burbeck, 1985; Burbeck \& Luce, 1982; Ejima \& Ohtani，1989）によって提唱されてきた.この概 念モデルは, 研究者によって詳細は異なるもの の, 基本的には神経生理学領域でよく知られてい る視覚，聴覚，皮膚感覚それぞれにおける持続型 (sustained/slowly adapting)および過渡型(transient/rapidly adapting）の感覚神経細胞の存在 に依拠している（Burbeck，1985; Johansson \& Vallbo, 1979; Sherrick \& Cholewiak, 1986). 持 続型細胞は比較的長い開始潜時を示し，刺激が呈 示されている限り反応を維持する，過渡型細胞は 刺激のオンあるいはオフのみに短潜時で反応する と考えられている，2 過程説では，単純反応時間 がこのような 2 種類の感覚細胞集団の活動を反 映していると仮定しており，例えば，Burbeck （1985）は，持続型細胞に対応する level detector と過渡型細胞に対応する change detector を想定 し, 両者の競争モデルによって刺激検出過程の説 明を試みている，また，これら持続型および過渡 型細胞による反応は，刺激の強度特性にも対応し ていると考えられている（Breitmeyer \& Ganz, 1976; Johansson \& Vallbo, 1979). 弱刺激に対し ては過渡型反応はきわめて弱く，持続型細胞が反 応を維持する．他方，強刺激に対しては過渡型の 細胞の反応がきわめて強くなる，感覚系にはこの ような 2 種類の細胞の反応をまとめて集積 （pool）する情報処理機構が存在し，その集積が 閾值を越えると刺激が検出されることになる。そ の後, さらに高次知覚過程（刺激の同定, 同時性 判断など）および運動準備過程が賦活されること になる (Ejima \& Ohtani, 1989).

知覚の 2 過程説に基づいて本研究の実験結果 を解釈すると，先行刺激はきわめて弱い刺激だっ たことから過渡型反応よりもむしろ持続型反応が 主として生じ，そのため一定レベルまでの集積に は相対的に長い時間がかかり, 結果として, 先行 
刺激を単独呈示した Weak 条件では反応時間が 長くなったとものと考えられる．後続刺激の強度 は大きかったので過渡型の反応が強く生じ, 後続 刺激を単独で呈示した Strong 条件下ではより短 い反応時間となったものと思われる.では逆向マ スキング・パラダイムの Double 条件の場合はど うかというと, 先行刺激による持続型の反応が既 にある程度集積したところに後続刺激による過渡 型の強い反応が積み重なったために, Strong 条 件の場合よりも短時間で反応集積が閾値に達し， その結果, 後続刺激の知覚処理がすばやく行われ 反応時間がより短くなったものと考えられる。 た, 先行刺激の知覚体験が生じなかったのは, 先 行刺激による持続型反応が後続刺激の過渡型反応 によって抑制あるいは中断されたからである（チ ヤンネル間㧕制, Breitmeyer \& Ganz, 1976) と 説明できる。

第 2 の可能性は時間加重説で，これは 2 過程 説をより単純化したものである. 個々の感覚入力 が閾値より小さくても，ある一定時間内に受容野 神経細胞群へ絽り返し与えられるとその入力が集 積 (加重) され, 集積量が閾值に達すると検出や 後の段階の知覚過程が始まる，という考え方であ る.この時間加重の概念は Bloch の法則（和気， 長谷川，1994，参照）としても古くから知られ ており, Saunders (1975)の実験データによれ ば，刺激呈示持続時間が $80 \mathrm{msec}$ 以下の場合，検 出感度はその持続時間に比例し，それ以上の呈示 時間になると感度はあまり変化しなくなる，本研 究の Double 条件下では, 先行刺激の呈示時間こ そ0.2 msec ときわめて短かったものの, 先行刺 激の $40 \mathrm{msec}$ 後に後続刺激が呈示されたことか ら，受容野細胞への時間加重は少なからず生じて いたはずである。したがって, Double 条件下の 方が後続刺激のみの Strong 条件よりも相対的に 感覚入力がより多く集積していたものと考えら れ, その結果, 後続刺激の検出やその後の知覚処 理がより短時間で遂行され反応時間が短くなった ものと推察される.

第 3 の可能性として, 本実験の結果を直接フ ライミング現象のひとつとして考えることも可能
かもしれない.すなわち，先行刺激が後続刺激の プライムとなって後続刺激の知覚処理を促進さ せ, 反応時間が短縮したという説明である.プラ イミング研究では, プライム刺激を瞬間呈示し被 験者が刺激を知覚できないようにした場合でも顕 著なプライミング効果がみられること（Marcel， 1983; McCauley et al., 1980）が報告されており, 本研究の結果を直接プライミング効果のひとつと して捉えることも可能と思われる. しかし, 直接 プライミングのメカニズムについては未だ確立し た見解がなく（太田，1991），本研究結果を直接 プライミング効果の点から整合的に説明するの は, 現時点では困難と思われる.

\section{3. 先行刺激による運動準備過程への影蚃}

前節における 3 つの解釈はいずれも，先行刺 激が後続刺激の知覚過程を活性化させるとする点 で共通しているが，もうひとつの解釈として，先 行刺激が知覚過程と並列的に運動準備過程を直接 活性化させた，という可能性も考えられる．例え ば，平松ら（1985）は事象関連電位のP P 300 と反 応時間に関する研究で, 刺激の認知・評価・判断 の処理を行う cognitive process，および反応選 択・運動反応の組織化や実行を遂行する behavior process を仮定し，これらの 2 つの処理過程 が刺激の入力以降，並列的に活性化・遂行される というモデルを提案している.この 2 つの処理 過程は,さらに上位の organizing systemによっ て相互の情報交換が効果的にコントロールされる と考えられている.このモデルでは, cognitive process の処理特性はP300に, behavior process の処理は反応時間にそれぞれ反映されると仮定し ており，P300の cognitive process と反応時間の behavior process $の$ 時間関係は organizing systemの働きによってさまさまに変化し得ることが 示唆されている.これについては, Nishihira et al. (1999) が，刺激や環境の条件によっては運動 反応としての筋収縮が P300の出現以前に開始す ることを実験的に示している．これらの知見を考 虑すると, 知覚一運動反応の情報処理では, 刺激 の認知・評価・判断などに基づいて運動準備過程 
が開始・遂行されるのではなく, むしろ知覚・認 知過程と並列的に運動準備過程が遂行されるとい う可能性が十分に考えられる．平松らのモデルに 基づけば，本研究の Double 条件の反応時間が Strong 条件の反応時間よりも短かったのは, 先 行刺激が知覚処理と同時に運動準備過程の処理を も活性化させ, その後に呈示された後続刺激の知 覚処理と並行して運動準備過程が進行したためと 推察することも可能であろう.

緒言で引用した Rossetti et al. (1995) の半側感 覚麻疩患者の例，あるいはWeiskrantzら (Weiskrantz, 1980; Weiskrantz et al., 1974)の blindsight の例む, 刺激からの感覚入力が知覚過 程を経ずに運動反応に直接貢献し得ることを示唆 している.これらの例は, 知覚過程が脳損傷のた めに遮断されているにもかかわらず刺激に対する 運動反応が顕著に生じたことを示している. Rossetti (2000) は，これらの知見を根拠に，刺激と 運動反応の直接結合あるいは知覚と行為の分離を 主張し，さらにその背景にある神経メカニズムに ついても, 以下のような神释経路に基ゔく可能性 を示唆している，すなわち，網膜あるいは皮局感 覚受容器からの感覚入力の処理経路に関しては, 一次視覚野, 一次体性感覚野を経て高次連合野に 至る神経経路とともに, 上丘・視床から一次感覚 野をバイパスする神経経路の存在が知られており,

Rossetti は, 一次感覚野を経由する経路が知覚体 験に至る処理を反映し, 他方のバイパス経路は知 覚体験を伴わずに運動反応に結びつく処理過程を 反映する，という概念モデルを提示している.こ のように，少なくとも神経経路として複数の感覚 ・認知処理系が存在していることを考虑すると, Rossetti の仮説モデルはひとつの興味深い考え方 を示しているといえる. しかし，現時点では，そ れらの神経経路と知覚体験の有無との対応関係に ついては明確な証拠は得られていない。

以上の幾つかの知見から, 運動準備過程が知覚 体験に基つかがに活性化され得ることがひとつの 可能性として示されたわけであるが，その場合， 運動準備過程は少なくとも無自覚的に開始される ことになる. 運動準備過程が無自覚的に開始され
るということについては, 最近の運動準備電位 (readiness potential, RP) に関する研究が興味深 い知見を報告している．RP は運動関連脳電位の うち最初に出現する陰性電位で, 筋出力に $800-$ $1500 \mathrm{msec}$ 先行して始まり小脳や大脳基底核, 視 床など広範な脳部位を発生源としている。これら のことから， RP は運動命令そのものではなく運 動の準備過程をひろく反映する電位であると考え られている (Deecke et al., 1976 ; 西平, 1991). 一般に，RP を含む運動関連脳電位の研究では意 図的に開始・遂行される随意動作が用いられてき た.これに対して Keller and Heckhausen (1990) は, 計数課題に伴って無意識的に生じた指折り動 作の RP をとりあげ，そのような無意識的な指折 り動作であっても, 通常の意図的運動とほぼ同じ 潜時で RP が生じることを示した.この結果は, RP が行為者の運動意図の有無に関わらず純粋に 運動準備過程そのものを反映していることを示唆 している.ささら， RP の立ち上がりが潜時800$1500 \mathrm{msec}$ と実際の筋活動よりかなり早い時点か ら出現することを考慮すると, ほとんどの場合, 運動準備過程は行為者の運動意図の意識化に先行 して始まるものと考えられる (Gomes, 1998). この点からみても, 運動準備過程は運動しようと する意図の意識化や刺激の知覚体験に基づいて始 まるのではなく，それ以前に既に無自覚的に開始 されているものと推察される.

本研究においては，既に述べてきたように， Double 条件下で呈示された先行刺激は，知覚体 験を伴わずにその後の情報処理に影響を及ほした むのと推察された．この先行刺激の情報処理が無 自覚下で遂行されたことと, 運動準備過程が無自 覚的に開始するという Keller and Heckhausen (1990) やGomes (1998) の知見は，ともに無自 覚下で進行する情報処理という点で共通してい る.この無自覚下の情報処理は, 少なくとも, 先 行刺激からの感覚入力が運動準備過程を直接活性 化させた可能性を説明するひとつの系口を提供し てくれるものと思われる. 
4. 逆向マスキング・パラダイム下の情報処理様 式一カスケード処理

逆向マスキング・パラダイムにおける情報処理 は, 部分的な並列処理ないしはカスケード型の処 理 (松岡, 1997 ; 松岡ほか, 1993; McClelland, 1979）によって遂行されているものと思われる. カスケード処理とは，ある処理がそれ自体の完了 前に次の処理段階を誘発し，それが次々にそれ以 降の処理を引き起こしていくという処理様式であ る.したがって, カスケード処理は, 部分的にみ れば並列処理様式を維持しつつ全体としては直列 的な処理が進行する処理様式といえる. 既に述べ てきたように，Double 条件下の先行刺激は，そ れが知覚体験に至る前に後続刺激の知覚過程を促 進し, 他方で運動準備過程をむ直接活性化させた 可能性が考えられる. したがって, 各情報処理過 程が完了する前にその後の処理を次々に引き起こ した可能性が高く, カスケード型の処理様式が進 行したものと推察される.

従来から，反応時間の情報処理は，Donders （1969）の減算法あるいは Sternberg（1969）の加 算法に典型的にみられるように，基本的には直列 処理モデルを仮定してきた。最近の教科書 (Schmidt \& Lee, 1999) でも, 刺激の同定, 反応 の選択, 反応のプログラミングといった一連の処 理段階からなる直列処理モデルが基本概念となっ ている.しかし，例えばSternberg (1969)のモ デルでは, 刺激変換と反応形成が同一処理ステー シ内蒮行すると考えられているなど，必ずしも 純粋な直列モデルだけが想定されてきたわけでは ない（積山，1994）. 最近の知覚運動制御モデル では, 行動的側面や事象関連電位などの観点か ら, 知覚と運動反応に関わるそれぞれの処理段階 が並列的に実行されるという並列処理モデル（平 松ほか, 1985; Rossetti, 2000), あるいは各処理 段階が重複しながら順次引き継がれていくという カスケードモデル（松岡, 1997; McClelland, 1979）が強調されるようになってきている.

これらの最近の考え方を考虑すると, 本研究結 果は, 层統的な直列処理よりもカスケード型の情 報処理モデルの方がより的確に知覚と運動の情報
処理を説明し得ることを示唆しているといえる. 今後は, さらに知覚と運動反応の背景にあるメカ ニズムの理解をより深めるために，刺激の検出過 程, 知覚体験を生じさせる認知過程, および運動 反応の準備過程の時間的・機能的関連性をより詳 細に検討していく必要があるものと思われる.

\section{要約}

本研究では，逆向マスキング・パラダイムを用 いた単純反応課題により，知覚体験を伴わない体 性感覚刺激の反応時間に及ほすす影響を検討した。

これまで，逆向マスキング・パラダイムによる知 覚と運動反応に関する研究の多くは視覚に関する もので，体性感覚については選択反応課題を用い た MacIntyre and McComas (1996) の研究が唯 一報告されているのみである。本研究では， MacIntyre and McComas の実験の問題点を考虑 し，選択反応課題に含まれる刺激弁別や反応選択 に関わる情報処理要因を除外するために単純反応 課題を採用した。本研究で用いた逆向マスキング ・パラダイムは，先行刺激（感覚閾值の1.2-1.5 倍強度）と後続刺激（4-5 倍強度）を $40 \mathrm{msec} の$ 間隔で呈示するという条件（Double 条件）とし， 比較のため, 先行刺激単独呈示 (Weak 条件), 後秸刺激単独呈示 (Strong 条件) を加えて反応 時間を検討した。なお, 被験者には, 強弱 2 種 類の刺激が呈示されること，およびいずれの刺激 に対してもできるだけすばやくマウスのクリック 動作を行うことのみを教示し, Double 条件での 刺激呈示については何も教示しなかった。

実験の結果, Double 条件の反応時間は後続刺 激単独呈示の Strong 条件よりも有意に短く，そ のときの被験者の知覚体験は後続刺激に対しての み生じ，先行刺激には生じていなかった．したが って，知覚体験を伴わなかった先行刺激がその後 に呈示された後続刺激の知覚過程や運動準備過程 に影響を及ぼし，その結果，反応時間が短くなっ たものと考えられた。これらの結果から，刺激一 反応の情報処理では，必ずしも刺激の知覚体験に 基づいてその後の情報処理が遂行されるのではな く, むしろ無自覚的な感覚入力が知覚・運動準備 
過程の促進 ・活性化に少なからず貢献することが 推察された。これに関して，刺激の検出と知覚体 験, 無自覚的刺激による知覚過程の促進と運動準 備過程への影響, および並列・カスケード型情報 処理モデルの諸点から考察を加えた.

\section{付記}

本論文は，筆頭著者の修士論文の一部を第 2 著者が中心となって新たな観点からまとめ直した ものである. また, 本研究の一部は, 日本スポー ツ心理学会第25回記念大会（大津）で発表した.

本研究の遂行にあたり,一部, 平成11年度文 部省科学研究費補助金基盤研究 C（課題番号 11680045 , 研究代表者今中国泰）の補助を受け た。記して感謝の意を表す。

\section{文献}

Abramsky, O., Carmon, A., and Benton, A. L. (1971) Masking of and by tactile pressure stimuli. Perception and Psychophysics 10: 353-355.

Breitmeyer, B. G. and Ganz, L. (1976) Implications of sustained and transient channels for theories of visual pattern masking, saccadic suppression, and information processing. Psychological Review 83: 1-36.

Burbeck, S. L. (1985) A physiologicallly motivated model for change detection in audition. Journal of Mathematical Psychology 29: 106-121.

Burbeck, S. L. and Luce, R. D. (1982) Evidence from auditory simple reaction times for both change and level detectors. Perception and Psychophysics 32 (2): 117-133.

Cheesman, J. and Merikle, P. M. (1986) Distinguishing conscious from unconscious perceptual processes. Canadian Journal of Psychology 40: 343-367.

Craig, J. C. and Evans, P. M. (1995) Tactile selective attention and temporal masking. Perception and Psychophysics 57: 511-518.

Deecke, L., Grözinger, B., and Kornhuber, H. H. (1976) Voluntary finger movement in man: Cerebral potentials and theory. Biological Cybernetics 23: 99119.

Donders, F. C. (1969) On the speed of mental processes. In W. G. Koster (Ed. and Trans.), Attention and performance II. Acta Psychologica 30: 412-431.

Ejima, Y. and Ohtani, Y. (1989) Analysis of simple reac- tion time to a sinusoidal grating by means of a linear filter model of the detection process. Perception and Psychophysics 46: 119-126.

Eriksen, C. W. and Collins, J. F. (1965) Reinterpretation of one form of backward and forward masking in visual perception. Journal of Experimental Psychology 70: 343-351.

Fehrer, E. and Biederman, I. (1962) A comparison of reaction time and verbal report in the detection of masked stimuli. Journal of Experimental Psychology 64: 126-130.

Fehrer, E. and Raab, D. (1962) Reaction time to stimuli masked by metacontrast. Journal of Experimental Psychology 63: 143-147.

Gomes, G. (1998) The timing of conscious experience: A critical review and reinterpretation of Libet's research. Consciousness and Cognition 7: 559-595.

Harrison, K. and Fox, R. (1966) Replication of reaction time to stimuli masked by metacontrast. Journal of Experimental Psychology 71: 162-163.

平松謙一 - 秋本優 $\cdot$ 丹羽真一 - 龟山知道 - 斎藤治 - 福 田正人 - 山崎清之 (1985) 選択反応課題における分裂 病患者の反応時間と P300潜時. 精神医学 27: 10551063.

Johansson, R. S. and Vallbo, A. B. (1979) Detection of tactile stimuli: Thresholds of afferent units related to psychophysical thresholds in the human hand. Journal of Physiology 297: 405-422.

Keller, I. and Heckhausen, H. (1990) Readiness potentials preceding spontaneous motor acts: Voluntary vs. involuntary control. Electroencephalography and clinical Neurophysiology 76: 351-361.

Kirman, J. H. (1984) Forward and backward tactile recognition masking. Journal of General Psychology 111: 83-99.

Laskin, S. E. and Spencer, W. A. (1979) Cutaneous masking. I. Psychophysical observations on interactions of multipoint stimuli in man. Journal of Physiology 42: 1048-1060.

Libet, B., Alberts, W. W., Wright, J., E. W., and Feinstein, B. (1967) Responses of human somatosensory cortex to stimuli below threshold for conscious sensation. Science 158: 1597-1600.

Libet, B., Wright, E. W., Feinstein, B., and Pearl, D. K. (1992) Retroactive enhancement of a skin sensation by a delayed cortical stimulus in man: Evidence for delay of a conscious sensory experience. Consciousness and Cognition 1: 367-375. 
Luce, R. D. (1986) Response times: Their role in inferring elementary mental organization. New York: Oxford University Press.

MacIntyre, N. J. and McComas, A. J. (1996) Non-conscious choice in cutaneous backword masking. NeuroReport 7: 1513-1516.

Marcel, A. J. (1983) Conscious and unconscious perception: Experiments on visual masking and word recognition. Cognitive Psychology 15: 197-237.

松岡洋夫（1997）刺激弁別と事象関連電位. 丹羽真一 - 鶴紀子編著 事象関連電位：事象関連電位と神経 情報科学の発展. 新興医学出版 : 東京, pp. 51-64.

松岡洋夫 · 斎藤秀光 ·上埜高志 - 佐藤光源 (1993) パ ターン認知および記憶探索に関係する視覚性事象関 連電位. 臨床脳波 35: 450-455.

McCauley, C., Parmelee, C. M., and Sperber, R. D. (1980) Early extraction of meaning from pictures and its relation to conscious identification. Journal of Experimental Psychology: Human Perception and Performance 6: 265-276.

McClelland, J. L. (1979) On the time relations of mental processes: An examination of systems of processes in cascade. Psychological Reviews 86: 287-330.

Neumann, O. and Klotz, W. (1994) Motor responses to nonreportable, masked stimuli: Where is the limit of direct parameter specification? In C. Umilta and $\mathbf{M}$. Moscovitch (Eds.), Attention and performance XV: Conscious and nonconscious information processing (pp. 123-150). Cambridge, MA: MIT Press.

西平賀昭 (1991) 運動準備電位. J. J. Sports Science 10(8): 540-545.

Nishihira, Y., Ohno, T., Hatta, A., Fumoto, M., Kaneda, T., Tokitou, S., Imanaka, K., and Funase, K. (1999) P300 before and after transient hard exercise. Advances in Exercise and Sports Physiology 5: 49 54.

太田信夫 (1991) 直接プライミング. 心理学研究 62(2): 119-135.

Raab, D., Fehrer, E., and Hershenson, M. (1961) Visual reaction time and the Broca-Sulzer phenomenon. Journal of Experimental Psychology 61: 193-199.

Rossetti, Y. (2000) Implicit perception in action: Shortlived motor representations of space. In P. G. Grossenbacher (Ed.), Finding consciousness in the brain: A neurocognitive approach: John Benjamins Publishing Company.

Rossetti, Y., Rode, G., and Boisson, D. (1995) Implicit processing of somaesthetic information: A dissocia- tion between where and how? NeuroReport 6: 506 510.

Saunders, R. McD. (1975) The critical duration of temporal summation in the human central fovea. Vision Research 15: 699-703.

Schiller, P. H. and Smith, M. C. (1966) Detection in metacontrast. Journal of Experimental Psychology 71: $32-39$.

Schmid, E. (1961) Temporal aspects of cutaneous interaction with two-point electrical stimulation. Journal of Experimental Psychology 61: 400-409.

Schmidt, R. A. and Lee, T. D. (1999) Motor control and learning: A behavioral emphasis. (3 ed.). Champaign, Illinois: Human Kinetic Publishers.

積山 黄 (1994) 反応時間. 大山正 . 今井省吾 - 和気 典二編 新編感覚・知覚心理学ハンドブック. 誠信 書房 : 東京, pp. 185-193.

Sherrick, C. E. and Cholewiak, R. W. (1986) Cutaneous sensitivity. In K. R. Boff, L. Kaufman, and J. P. Thomas (Eds.), Handbook of perception and human performance: Vol. 1. Sensory processes and perception (Chapter 12). New York: John Wiley and Sons.

Sternberg, S. (1969) The discovery of processing stages: Extensions of Donders' method. In W. G. Koster (Ed.), Attention and performance II. Acta Psychologica 30: 276-315

Taylor, J. L. and McCloskey, D. I. (1990) Triggering of preprogrammed movements as reactions to masked stimuli. Journal of Neurophysiology 63: 439-446.

Taylor, J. L. and McCloskey, D. I. (1996) Selection of motor responses in the basis of unperceived stimuli. Experimental Brain Research 110: 62-66.

Thompson, J. H. (1966) What happens to the stimulus in backward masking? Journal of Experimental Psychology 71: 580-586.

Ulrich, R., Rinkernauer, G., and Miller, J. (1998) Effects of stimulus duration and intensity on simple reaction time and response force. Journal of Experimental Psychology: Human Perception and Performance 24: 915-928.

和気典二 - 長谷川敬 (1994) 視感覚の時間的側面. 大 山正 · 今井省吾 - 和気典二編 新編感覚 - 知覚心理 学ハンドブック. 誠信書房 : 東京, pp. 335-339.

Weiskrantz, L. (1980) Varieties of residual experience. Quarterly Journal of Experimental Psychology 32: 365-386.

Weiskrantz, L., Warrington, E. K., Sanders, M. D., and Marshall, J. (1974) Visual capacity in the hemianopic 
field following a restricted occipital ablation. Brain 97: 709-728.

White, C. W. (1976) Visual masking during pursuit eye movements. Journal of Experimental Psychology: Hu- man Perception and Performance 2: 469-478.

平成11年 6 月 11 日受付

平成11年11月27日受理 